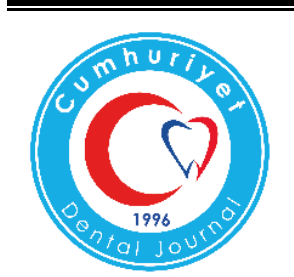

\title{
REPETITIVE REGENERATIVE ENDODONTIC PROTOCOL TREATMENT \\ FOR MATURE TEETH WITH DENS INVAGINATUS AND SEVERE \\ PERFORATED INTERNAL ROOT RESORPTION: A CASE REPORT WITH 24- MONTH FOLLOW-UP
}

\begin{abstract}
The association of internal root resorption (IRR) with dens invaginatus is an extremely rare finding, and its incidence may be underestimated, adding to the difficulty of endodontic treatment. A 9-year-old boy was admitted with complaints of swelling and pain. Radiological examination revealed closed apex Oehlers type II dens invaginatus and severe IRR, as well as apical third of two lateral root perforation and lesion. Calcium hydroxide applied in the regenerative endodontic protocol (REP) as intracanal medicament. Differently, bleeding was achieved by irritating the lateral perforation area. However, the tooth showed spontaneous pain and sensitivity to percussion after 2 months. The same REP was performed, but a triple antibiotic paste was used as the intracanal medicament. After 2 years, the tooth was asymptomatic, and radiographic examination revealed the decrease was cared on the previous resorption sites, and one of the openings on the lateral root surface had closed.
\end{abstract}

Key words: Cone-beam computed tomography, dens invaginatus, internal root resorption, regenerative endodontic treatment, triple antibiotic paste.
Tuğba Yigit ${ }^{1}$

Hakan Arslan ${ }^{2}$

ORCID IDs of the authors:

T.Y. $\quad 0000-0002-8742-9031$

H.A. $\quad 0000-0003-4890-1062$

\footnotetext{
${ }^{1}$ Department of Pediatric Dentistry, Faculty of Dentistry, Uşak University, Uşak, Turkey.

2 Department of Endodontics, Faculty of Dentistry, Health Sciences University, Istanbul, Turkey.
}

$\begin{array}{ll}\text { Received } & : 08.03 .2021 \\ \text { Accepted } & : 15.06 .2021\end{array}$

How to Cite Yigit T, Aslan H. Repetitive Regenerative Endodontic Protocol Treatment for Mature Teeth with Dens Invaginatus and Severe Perforated Internal Root Resorption: A Case Report with 24-Month Follow-Up. Cumhuriyet Dent J 2021;24:3:274-280.

*Corresponding Author:

Department of Pediatric Dentistry, Faculty of Dentistry, Uşak University, Uşak, Turkey.

Phone: +905078502596 $\quad$ Fax: + $902762212232 \quad$ E-mail: tugba.yigit@usak.edu.tr 


\section{INTRODUCTION}

Regenerative endodontic protocol (REP) is a valuable therapeutic treatment alternative to increase tooth survival of necrotic and immature teeth. ${ }^{1}$ Recently, REP has been the choice to treat necrotic pulp and apical periodontitis in mature teeth. $^{2,3}$ The disinfected canals are filled with biocompatible, nonvital foreign materials in root canal therapy, while in REP, different from this classic treatment, the canals are filled with vital tissue.

Dens invaginatus is a developmental structure pathology caused by the progression of enamel and dentin toward pulp before the completion of tooth calcification. Tooth invagination is limited by tooth crown or can extend to the apex of the root. ${ }^{4}$ It is thought that trauma, infection, growth retardation in specific cells, the disruption of factors that enable enamel development, and genetic factors influence dens invaginatus etiology. ${ }^{5}$ The phenomenon's prevalence varies from $0.3 \%$ to $10 \%$, most frequently affecting the maxillary lateral and central incisors, respectively, and may occur bilaterally. ${ }^{6}$ The clinical importance of dens invaginatus involves increased caries, periodontal inflammation, and pulp necrosis risk due to abnormal morphological plaque retention in the invagination area. ${ }^{7}$ Treatment options include canal treatment; however, irregularly shaped canal structures may cause additional problems.

Odontoclastic activity related to chronic pulp inflammation and trauma cause a resorptive defect in the internal root known as internal root resorption (IRR). Other etiological factors may be continuous pulpotomy, pathogenic irritation and infections, transplantation procedures, cracks, and orthodontic treatment. ${ }^{8,9}$ Maintaining the integrity of the tooth is important in the early diagnosis and accurate management of IRR. ${ }^{9}$ The treatment process could grow more difficult if the resorption area starts to perforate the root canal system, though recalcification treatment and/or surgical approaches using calcium hydroxide $\left(\mathrm{Ca}(\mathrm{OH})_{2}\right)$ have been suggested as an alternative treatment. ${ }^{10}$

In IRR cases, REP may be a sufficient treatment ${ }^{11,12}$, as it is more conservative and may significantly contribute to tooth retention. Therefore, the target of this case report is to feature REP as used to treat a mature permanent tooth with dens invaginatus and perforated IRR.

\section{Case Report}

A 9-year-old boy was admitted to the Department of Pediatric Dentistry at XXX University with complaints of swelling and pain. His medical history was not clear. Clinically, the crown of the maxillary left lateral incisor (\#10) was without caries. There was swelling of the palatinal region. The type 2 mobile tooth was sensitive to percussion and palpation. Electric (Vitality Scanner; Analytic Technology, Glendora, CA, USA) and thermal (Endo-Ice; The Hygenic Corporation, OH, USA) pulp sensitivity testing was negative only for tooth $\# 10$, while the adjacent teeth presented normal responses. There were no pathological periodontal pockets in any of the teeth in the left maxillary region. Radiological examination revealed closed apex Oehlers type II dens invaginatus and severe IRR, as well as apical third of two lateral root perforation and lesion. (Figure 1A).

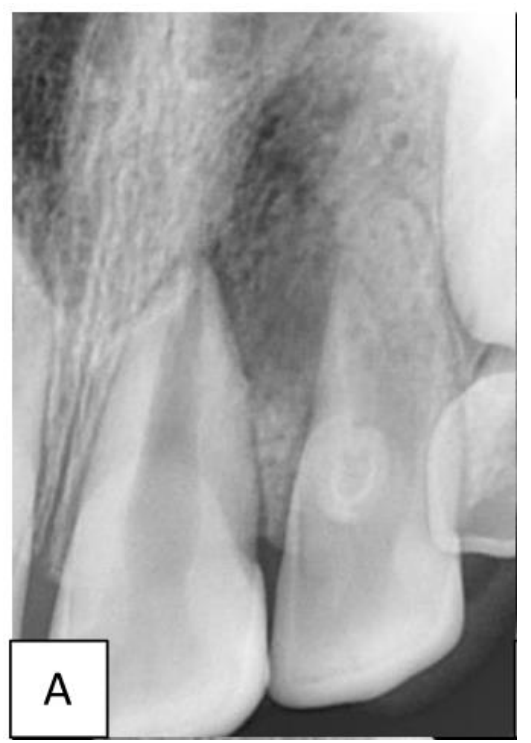

Figure 1 Preoperative (A), 1 month recall

The patient's parent was informed of all the possible modalities, risks, and benefits of the recommended REP treatment. Under local anesthesia (infiltration of $2 \%$ Lidocaine with 1:100,000 epinephrine), a rubber dam was inserted in the patient's mouth. After the invagination area was passed with a diamond bur, suppurative yellowish fluid was drained. No instrumentation was performed. For gentle root canal irritation, 20 
$\mathrm{ml} 1.25 \%$ sodium hypochlorite $(\mathrm{NaOCl})$ was used, and the area was dried with sterile paper points. A calcium hydroxide powder (Sultan Chemists Inc., Englewood, NJ, USA) and sterile water mixture was placed in the pulp chamber with an ISO \#25 $\mathrm{K}$-file. A glass ionomer restoration was inserted for temporary use (Fuji IX; GC America, Alsip, IL, USA). After 4 weeks, the tooth was asymptomatic and anesthetized with $2 \%$ mepivacaine, then isolated with a rubber dam. The dressing paste was irrigated with $10 \mathrm{ml}$ sterile saline for removal, dried with sterile paper points, irrigated again with $20 \mathrm{ml}$ $17 \%$ ethylenediaminetetraacetic acid (EDTA, Merck, Darmstadt, Germany), and dried again. The periapical tissues of the lateral perforation area were irritated without touching the apical area, as performed with an ISO \#25 K-file. Bleeding reached a minimum of $3 \mathrm{~mm}$ below the cementoenamel junction in 5 minutes. A mineral trioxide aggregate (MTA; MTA-A; Angelus, Londrina, Brazil) plug was gently placed on the blood clot. The MTA was protected with a moist sterile cotton pellet and the entrance sealed with a temporary glass ionomer restoration Cavit $\mathrm{G}(3 \mathrm{M}$ ESPE Dental-Medizin GmbH Co, Seefeld, Germany). One week later, FujiIX glass ionomer cement (Fuji Corporation, Osaka, Japan) and a composite (Filtek Z250; 3M ESPE) were placed for the final restoration.

However, the tooth showed spontaneous pain and sensitivity to percussion after 2 months. Cone beam computed tomography (CBCT) scans generated a three-dimensional image of the tooth. A severe perforation region on the root surface was observed in axial, sagittal, and coronal CBCT cross-sections (Figs. 2A-C).

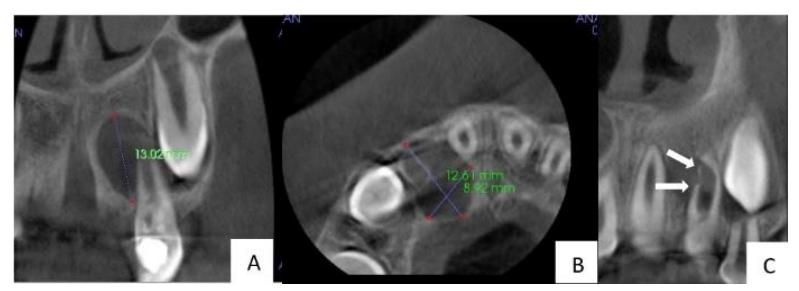

Figure 2 3-month recall CBCT of the patient (before the repetitive REP)

The mesial and distal surfaces of the tooth had resorbed, and the resorption process distally occupied the periodontal ligament of the central tooth (Figure 2A). The cortical bone was completely resorbed in the tooth's palatinal region as well (Figure 2A). The resorption area measured $8.92 \times 12.61 \times 13.02 \mathrm{~mm}$ with a software measurement tool (CS 3D Imaging Software version 3.1.9; Carestream Dental LLC, Atlanta, GA, USA; Figs. 2A, B). Also, apical third of two lateral root perforation were detected (Figure 2C).

The initial regenerative stimulation was considered ineffective, and for this reason, REP was repeated. A rubber dam was placed in the patient's mouth under local anesthesia. The composite resin restoration and MTA were removed with a diamond bur. The same REP was performed, but a triple antibiotic paste was used as the intracanal medicament. Triple antibiotic paste, clindamycin, ciprofloxacin, and metronidazole were mixed equally (all from Sigma- Aldrich, St. Louis, MO, USA) with sterile water to generate triple antibiotic paste (TAP) at a concentration of 1 $\mathrm{mg} / \mathrm{ml}$. In addition, in this second REP appointment, the antibiotic paste was removed via copious irrigation with $1.25 \% \mathrm{NaOCl}$ and thereafter with $10 \mathrm{~mL}$ sterile distilled water. The root canals were slowly irrigated with $20 \mathrm{~mL} 17 \%$ EDTA but first dried with sterile paper points.

Healthy soft tissues were noted at the patient's 6-, 12-, 18-, and 24-month follow-up appointments (Figs. 1B-E).

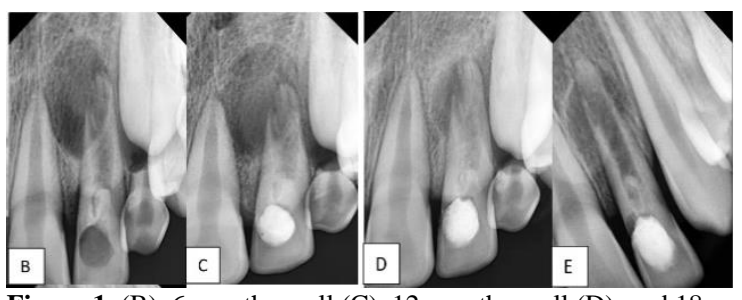

Figure 1. (B), 6-month recall (C), 12-month recall (D), and 18month recall $(\mathrm{E})$ radiographs of the patient.

The tooth had a negative response to vitality testing. Especially the lateral lesion's healing after 6 months was observed via periapical radiographic examination (Figure 1C). When the CBCT images taken in the third and the twenty-fourth months were compared, it was observed that the lesion had been surrounded by sclerotic borders, demonstrating the healing of all tooth surfaces; the decreasing area was very excited compared to the previous resorption sites. Measurements demonstrated that the resorption area had decreased to $2.40 \times 5.21 \times 5.31 \mathrm{~mm}$. The thickness of 
the lateral walls also increased relatively, and one of the openings on the lateral root surface had closed (Figure 3A, B).

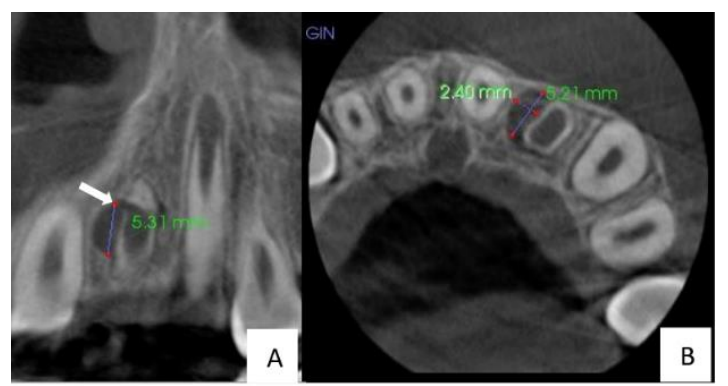

Figure 3 24-month recall CBCT of the patient

\section{DISCUSSION}

Dens invaginatus is a common dental occurrence; however, it cannot be easily diagnosed due to a lack of specific clinical signs. It is still clinically important because it serves as an ideal harbor for plaque and microorganisms from where focal periodontitis can begin. Clinicians have had difficulty determining a clinical approach after diagnosing dens invagination. ${ }^{13}$ Current dens invaginatus treatment options include non-surgical endodontic treatment of the infected invagination, ${ }^{14-16}$ treatment of the entire root canal system, ${ }^{17-19}$ combined endodontic and surgical therapy ${ }^{20-22}$ and REP. ${ }^{23,24}$ Although there are no clinical studies on REP treatment for dens invaginatus, there are a limited number of case reports. The success of REP can be evaluated as reaching primary, secondary, and tertiary goals. Of course, the primary goal is healing the bone and eradicating symptoms. The secondary goal, then, is to increase root wall thickness/length, and the tertiary goal is the positive response to vitality testing. In the presented case, treatment success was limited to the primary and secondary goals.

Wedenberg and Lindskog ${ }^{25}$ reported that IRR can be a transient or progressive event and researchers damaged the root canal predentin of 32 primate incisors. While some of the cavities had closed, those remaining were left open in the oral cavity. Multinucleated clastic cells in the closed teeth showed a temporary colonization, that is, temporary internal resorption. There was no bacterial contamination or active hard tissue resorption. In the group associated with the oral cavity, the damaged dentin surface showed signs of long-term clastic cell colonization and progressive
IRR. Bacterial contamination was also seen in the pulp tissue and dentinal tubules. According to Wedenberg and Lindskog ${ }^{25}$, internal resorption does not progress when bacterial stimulation is blocked. In fact, with REP treatment, bacteria are removed from the canal. As such, in the current case, internal resorption did not progress.

One hypothesis is that osteocytes reduce osteoclastogenesis activity by decreasing actin ring production (active resorbing cells) and playing an important role in bone homeostasis. ${ }^{26}$ However, if osteocytes die via apoptosis, osteoclastogenic cytokines become active in bone resorption again. ${ }^{27}$ At the time of tooth development, dental pulp cells and odontoblasts behave as osteocytes and choose apoptotic pathways when they encounter injury. ${ }^{28}$ Considering that dens invaginatus is a developmental dental anomaly, it may be that there is a situation in which odontoblasts may be damaged in the process, and dens invagination may be a source of chronic infection; therefore, a tendency for internal resorption may increase. Since no findings in this case led to internal resorption, it can be considered that the pulp inflammation caused by the deep invagination of the lateral incisor caused internal resorption. As a matter of fact, in a recent study, dens invaginatus and its relationship with internal resorption drew attention. ${ }^{29}$

Blood in the pulp tissue at the apical region of the resorptive lesion is essential for providing clastic cells nutrients to form internal resorption, though these cells can be stimulated by the infected necrotic coronal pulp tissue as well. ${ }^{9}$ In addition, in the current case, the occurrence of apical closure showed that vital tissues were present in the apical pulp but absent in periapical pathology. Bleeding was achieved from the lateral perforation area without touching the apical area so as not to damage the apical vital tissues.

The colonization of bacteria on the canal walls and their insufficient debridement were the main reason for this case's unsuccessful initial treatment. A recently published report also noted this knowledge, informing that histo-bacteriologic analysis underlines failed revascularization and 
revitalization therapy. ${ }^{30}$ The main reason for the first treatment's failure in that case were intra-canal microorganisms in a root canal that remained empty after the completion of possible single-stage disinfection protocols.

Alternative treatments may not have been successful in the current case, as both of the tooth's lateral walls were very thin, with even the root surface having openings in two places, so REP treatment was repeated. Optimum disinfection of the root canal system using intracanal medicaments is considered an important step in REP. ${ }^{31}$ The used intracanal medicaments in REP are triple (ciprofloxacin, metronidazole, and minocycline) or double (ciprofloxacin and metronidazole) antibiotic combinations ${ }^{32}$ and $\mathrm{Ca}(\mathrm{OH})_{2}{ }^{33,34}$ In the present case report, $\mathrm{Ca}(\mathrm{OH})_{2}$ was preferred as the intracanal medicament to remove the necrotic residual pulp tissues, eliminate osteoclastic activity, and control bleeding. When the first treatment failed, TAP was preferred in the second treatment to more effectively disinfect the area. Nevertheless, $\mathrm{Ca}(\mathrm{OH})_{2}$ shows low solubility and inactivation in dentin, tissue fluids, and organic matter, so it is not sufficient to prevent bacterial colonization. ${ }^{35}$ Indeed, intracanal antibiotic medicaments showed more benefits when compared to traditional $\mathrm{Ca}(\mathrm{OH})_{2}$ in recent in vitro studies. ${ }^{36}$ However, it has also been reported to produce cytotoxic effects in apical papillae stem cells $^{37}$, pulp stem cells ${ }^{38}$, and pulp fibroblasts. ${ }^{39}$ Therefore, research has found that $\mathrm{Ca}(\mathrm{OH})_{2}$ or a double or triple antibiotic paste of a low concentration $(0.1-1 \mathrm{mg} / \mathrm{mL})$ sufficiently provides an effective antimicrobial drug without damaging the pluripotent stem cells within the root canal system. ${ }^{40}$ For this reason, a TAP of $1 \mathrm{mg} / \mathrm{mL}$ was preferred in this study.

In a comparison study by Patel et $a l .{ }^{41}$, intraoral periapical radiography proved more effective than CBCT in diagnosing and maintaining root resorption episodes. Therefore, in the present case, the initial use of periapical radiographic imaging may have been a limitation to determining the resorption area and dentine wall thickening. However, CBCT was used after the failure for detailed examination of root canal, as three-dimensional examination allows clinicians to evaluate the internal tooth for a more complete diagnosis and treatment plan. ${ }^{42}$

The association of IRR with dens invaginatus is an extremely rare finding, and its incidence may be underestimated, adding to the difficulty of endodontic treatment. Root canal treatment was used in two published case reports without bone resorption. ${ }^{43,44}$ This study can contribute to the literature as the first case report in which REP was used as an alternative treatment option in these cases. Still, more research is necessary to find a relation between IRR and dens invaginatus.

\section{$\ddot{O} Z$}

Internal kök rezorpsiyonunun (IKR) dens invaginatus ile ilişkisi son derece nadir bir bulgudur ve endodontik tedavinin zorluğuna ek olarak insidansl hafife alınabilir. Dokuz yaşında erkek çocuk hasta, şişlik ve ăgrt şikayetleri ile kliniğimize başvurdu. Radyolojik incelemede, kapall apeks, Oehlers tip II dens invaginatus ve şiddetli IKR, ayrlca apikal üçlüde iki lateral kök perforasyonu ve apikal lezyon görüldü. Rejeneratif endodontik protokolde (REP) kanal içi medikament olarak kalsiyum hidroksit uygulandl. Farklı olarak lateral perforasyon alanından kanama sağlandl. Ancak, 2 ay sonra ağr ve perküsyona duyarlllık nedeni ile REP tekrar edildi. Bu uygulamada kanal içi medikament olarak üçlü antibiyotik pat kullanıldı. 2 yll sonra dis asemptomatikti ve radyografik incelemede rezorpsiyon alaninda küçülme ve lateral kök yüzeyindeki açıkllklardan birinin kapandığı görüldü. Anahtar kelimeler: Dens invaginatus, internal kök rezorpsiyonu, konik ışınlı bilgisayarl tomografi, rejeneratif endodontik tedavi, üçlü antibiyotik pat.

\section{REFERENCES}

1. Law AS. Considerations for regeneration procedures. J Endod 2013;39:44-56.

2. Arslan H, Ahmed HMA, Şahin Y, et al. Regenerative Endodontic Procedures in Necrotic Mature Teeth with Periapical Radiolucencies: A Preliminary Randomized Clinical Study. J Endod 2019;45:863-872.

3. Saoud TM, Sigurdsson A, Rosenberg PA, et al. Treatment of a large cystlike inflammatory periapical lesion associated with mature necrotic teeth using regenerative endodontic therapy. J Endod 2014;40:2081-2086. 
4. Hülsmann M. Dens invaginatus: aetiology, classification, prevalence, diagnosis, and treatment considerations. Int Endod J 1997;30:79-90.

5. Teixidó M, Abella F, Duran-Sindreu F, et al. The use of cone-beam computed tomography in the preservation of pulp vitality in a maxillary canine with type 3 dens invaginatus and an associated periradicular lesion. $\mathbf{J}$ Endod 2014;40:1501-1504.

6. Alani A, Bishop K. Dens invaginatus. Part 1: classification, prevalence and aetiology. Int Endod J 2008;41:1123-1136.

7. Clarke P, Longridge N, Gartshore L. A multidisciplinary management of a type III dens invaginatus in a maxillary permanent canine. Eur Arch Paediatr Dent 2016;17:131-136.

8. Haapasalo M, Endal U. Internal inflammatory root resorption: the unknown resorption of the tooth. Endodontic Topics 2006;14:60-79.

9. Patel S, Ricucci D, Durak C, et al. Internal root resorption: a review. J Endod 2010;36:1107-1121.

10. Nilsson E, Bonte E, Bayet F, et al. Management of internal root resorption on permanent teeth. Int $\mathrm{J}$ Dent 2013;2013:929486.

11. Saoud TM, Mistry S, Kahler B, et al. Regenerative Endodontic Procedures for Traumatized Teeth after Horizontal Root Fracture, Avulsion, and Perforating Root Resorption. J Endod 2016;42:1476-1482.

12. Kaval ME, Güneri $P$, Çalışkan MK. Regenerative endodontic treatment of perforated internal root resorption: a case report. Int Endod J 2018;51:128-137.

13. Kogon SL. The prevalence, location and conformation of palato-radicular grooves in maxillary incisors. J Periodontol 1986;57:231-234.

14. Teixido M, Abella F, Duran-Sindreu F, et al. The use of cone-beam computed tomography in the preservation of pulp vitality in a maxillary canine with type 3 dens invaginatus and an associated periradicular lesion. J Endod 2014;40:1501-1504.

15. Keles A, Cak1c1 F. Endodontic treatment of a maxillary lateral incisor with vital pulp, periradicular lesion and type III dens invaginatus: a case report. Int Endod J 2010;43:608-614.

16. Kfir A, Telishevsky-Strauss Y, Leitner A, et al. The diag- nosis and conservative treatment of a complex type 3 dens invaginatus using cone beam computed tomography (CBCT) and 3D plastic models. Int Endod J 2013;46:275-288.

17. Agrawal PK, Wankhade J, Warhadpande M. A rare case of type III dens invaginatus in a mandibular second premolar and its non- surgical endodontic management by using cone-beam computed tomography: a case report. J Endod 2016;42:669-672.

18. Nosrat A, Schneider SC. Endodontic management of a maxillary lateral incisor with 4 root canals and a dens invaginatus tract. J Endod 2015;41:1167-1171.

19. Brooks JK, Ribera MJ. Successful nonsurgical endodontic outcome of a severely affected permanent maxillary canine with dens invaginatus oehlers type 3 . J Endod 2014;40:1702-1707.

20. Fregnani ER, Spinola LFB, Sonego JRO, et al. Complex endodontic treatment of an immature type III dens invaginatus. A case report. Int Endod J 2008;41:913-919.

21. Vier-Pelisser FV, Pelisser A, Recuero LC, et al. Use of cone beam computed tomography in the diagnosis, planning and follow up of a type III dens invaginatus case. Int Endod J 2012;45:198-208.

22.Zoya A, Ali S, Alam S, et al. Double dens invaginatus with multiple canals in a maxillary central incisor: retreatment and managing complications. J Endod 2015;41:1927-1932.

23. Narayana P, Hartwell GR, Wallace R, et al. Endodontic clinical management of a dens invaginatus case by using a unique treatment approach: a case report. J Endod 2012;38:1145-1148.

24. Kumar H, Ali MA, Parashos P, et al. Management of 2 teeth diagnosed with dens invaginatus with regenerative endodontics and apexification in the same patient: a case report and review. J Endod 2014;40:725731.

25. Wedenberg C, Lindskog S. Experimental internal resorption in monkey teeth. Endod Dent Traumatol 1985;1:221-227.

26. Heino TJ, Hentunen TA, Vaananen HK. Osteocytes inhibit osteoclastic bone resorption through transforming growth factor-beta: enhancement by estrogen. J Cell Biochem 2002;85:185-197. 
27. Cardoso L, Herman BC, Verborgt O, et al. Osteocyte apoptosis controls activation of intracortical resorption in response to bone fatigue. J Bone Miner Res 2009;24:597-605.

28. Kitamura C, Ogawa Y, Morotomi T, et al. Differential induction of apoptosis by capping agents during pulp wound healing. J Endod 2003;29:41-43.

29. Pérez-Alfayate R, Mercadé $M$, Vera J. Relationship between internal root resorption and dens in dente. $\mathbf{J}$ Clin Exp Dent 2020;12:e800-e804.

30. Iwaya SI, Ikawa M, Kubota M. Revascularization of an immature permanent tooth with apical periodontitis and sinus tract. Dent Traumatol 2001;17:185-187.

31. Ding RY, Cheung GS, Chen J, et al. Pulp revascularization of immature teeth with apical periodontitis: a clinical study. J Endod 2009;35:745749.

32. Trope M. Treatment of the immature tooth with a non-vital pulp and apical periodontitis. Dent Clin North Am 2010;54:313-324.

33. Cehreli ZC, Isbitiren B, Sara S, et al. Regenerative endodontic treatment (revascularization) of immature necrotic molars medicated with calcium hydroxide: a case series. J Endod 2011;37:1327-1330.

34. European Society of Endodontology Position Statement. Revitalization procedures. Int Endod J 2016;49:717-723.

35. Ricucci D, Siqueira JF Jr. Apical actinomycosis as a continuum of intraradicular and extraradicular infection: case report and critical review on its involvement with treatment failure. J Endod 2008;34:1124-1129.

36. Jacobs JC, Troxel A, Ehrlich Y, et al. Antibacterial effects of antimicrobials used in regenerative endodontics against biofilm bacteria obtained from mature and immature teeth with necrotic pulps. J Endod 2017;43:575-579.

37. Althumairy RI, Teixeira FB, Diogenes A. Effect of dentin conditioning with intracanal medicaments on survival of stem cells of apical papilla. J Endod 2014;40:521-525.

38. Alghilan MA, Windsor LJ, Palasuk $J$, et al. Attachment and proliferation of dental pulp stem cells on dentine treated with different regenerative endodontic protocols. Int Endod J 2017;50:667-675.

39. Kim KW, Yassen GH, Ehrlich Y, et al. The effects of radicular dentine treated with double antibiotic paste and ethylenediaminetetraacetic acid on the attachment and proliferation of dental pulp stem cells. Dent Traumatol 2015;31:374-379.

40. American Association of Endodontists. AAE clinical considerations for a regenerative procedure. Available at: https://www.aae.org/uploadedfiles/publications_and_ research/research/currentregenerativeendodonticconsidera tions.pdf.

41. Patel S, Dawood A, Wilson R, et al. The detection and management of root resorption lesions using intraoral radiography and cone beam computed tomography: an in vivo investigation. Int Endod $\mathbf{J}$ 2009;42:831-838.

42. Patel S, Durack C, Abella F, et al. European Society of Endodontology position statement: the use of CBCT in endodontics. Int Endod J 2014;47:502-504.

43. Sawant PH, Nilker V, Mandke L. Resorption in the maxillary incisor with dens invaginatus. J Indian Acad Dent Spec Res 2015;2:83-86.

44. Kirzioglu Z, Çiftçi ZZ. Internal resorption in an incisor with dens invaginatus. $J$ Pediatr Dent 2014;2:101-104. 